\title{
TOWARD BUILT ENVIRONMENT AS AN OPEN SYSTEM
}

\begin{abstract}
Almantas SAMALAVIČIUS
This issue of the journal was originally intended to focus on the relations and controversies between landscape architecture and ecology - a theme that seemed to be full of potential to attract a large amount of interesting and prospective scholarly submissions to make up a special issue, even more so since the global awareness of the failed relationship between the natural and the built environment in the Modern era has been growing recently, and the present state of affairs, due to highly unprecedented megalomaniac urban growth as well as its side-effects, has become especially worrisome. While I was anticipating a vast array of interesting submissions focused on the proposed theme, the guest editor of the issue unexpectedly resigned to my great surprise and dismay, with the excuse that she had encountered very limited interest in the topic, most possibly, as she presumed, because a number of other academic, architectural journals had recently dealt with various aspects of this recurrent theme. Whatever were the reasons that induced our guest editor to give up her voluntary commitment, I finally saw no other option than to publish a regular issue instead of the planned thematic one - having in mind that the notification about the cancelled issue came somewhat too late to consider the plausible options either of replacing the guest editor or extending the deadline for submissions.

Despite the fact that the present articles are now being published in a thematically varied issue and all except one were mailed to us as regular submissions, one can still notice an ecological concern that surfaces in the articles so different in scope, geography, and approach. Though they are all focused on their own particular issues, nevertheless, most of them seem to share a common understanding that the way architecture and urbanism was supposed to function during the greater part of the last century have in fact not performed as expected. Thus, new and fresh approaches

are needed to overcome the burdensome legacy of the Modern era. In his insightful and penetrating article, Malcolm Millais offers a critical and timely reconsideration of the highly ambiguous legacy of Le Corbusier a figure that has immensely influenced and even dominated Modernist architectural and urban ideologies as well as critical discourses of the last century. Millais focuses on his "exemplary" piece of urbanism - those so much admired, praised, and glorified Marseille housing blocks that for a number of decades remained "tax-exempt" from adequate critical scrutiny despite volumes of scholarship written on him as one of the founding-fathers of architectural Modernism. While editing this issue, coincidentally, I came across Millais book, Exploding the Myths of Modern Architecture (London: Frances Lincoln), published some seven years ago, and I found it quite provocative and interesting. It remains surprisingly ignored to this very day despite the fact that critical revisions of architectural Modernism as well as its unsustainable practices are far more numerous than two or three decades ago. And yet a truly critical discourse of architectural Modernism is still in the making. In the final chapter of his book, Millais comes up with very uncomfortable questions. While ending a lengthy discussion of the last century's architectural shortcomings and arguing that even modern architecture has proven to be an explicit failure to most people - its clients and users - he remarks that it is still surprisingly treated as "a great success" by a vast majority of architectural practitioners. He then asks, "Was the Modern movement right to reject every aspect of the past, root and branch in the way it did? Was there really no alternative, did it just have to be this way? While books on modern architecture are replete with damning comments about individual buildings, there is no blanket condemnation, no suggestion that the Modern Movement can be seen as a virus that has infected the architectural profession globally." A tough
\end{abstract}


question. I have no doubt that some professionals and academics would be all too easily willing to dismiss such questions as being "fundamentalist" - a term that has acquired, perhaps, somewhat too straightforward and superficial a meaning in contemporary political and cultural discourse. However, I see such questioning as extremely important. Moreover so, since all over the globe we are witnessing a total collapse not just of some particularly "iconic" contemporary edifices built while cynically disregarding their functional aspects and performability, building costs, energy-consumption and many other elementary standards any truly human shelter should meet, but something that might be called a systematic failure of the whole ideology that shaped this aesthetics and approach to building. And while the war on iconism seems to have finally been waged both in Europe and America, the whole "malpractice" of modern architectural and urban industrial enterprise still remains largely unquestioned and unexamined. Of course, some of the recent books on architectural and urban legacy of the last century contain a lot of criticism, and their number seems to be constantly growing, providing a moderate hope that urgent questions concerning our existing architectural environment will be adequately addressed and examined; however, there is an urgent need to go deeper and beyond a conventionally superficial or fragmentary critique of modern architecture and urbanism. Contemporary urban development, among other things, is also closely related to Modernist ideology and the urban planning legacy of the last century. Renowned architectural critic Kenneth Frampton in our recent exchange, has discussed some current global tendencies in urbanism and has explicitly insisted that, "It is clear that ongoing suburbanization is essentially an elaborate unspoken conspiracy between the oil companies, the automobile industry, the mortgage system, local building regulations, and the home building industry, along with the continental-wide super-market chains. This ecological "endgame" was clearly foreseen a long time ago by Henryk Skolimowski in his remarkable little book titled EcoPhilosophy." It could be added, though, that architects as well as urban planners and urban designers voluntary or involuntary play their role in these processes. Even if their role is far from being the most significant (though sometimes the public image of "starchitects" suggests such an illusion), the architectural profession, at the same time, cannot be classified as "tax-exempt" in this respect. A change of mental attitudes is urgently needed. In fact a lot of these issues have recently been targeted in a book Design for a Living Planet (Portland, Oregon: Sustasis Press, 2015), co-written by Michael W. Mehaffy and Nikos A. Salingaros - a brilliant critical discussion of contemporary architectural enterprise as well as guidelines to a practice that might be labeled as reasonably sound, truly functional, sustainable and resilient, and meeting basic human aesthetic needs. The authors of this wise and insightful book, devoid of the usual academic "jargon", address the issues of a built environment that need not only fresh insight but also changes in the practical realm. What I find highly appealing in this remarkably concise book, is the ability of its authors to apply scientific concepts to the practice of design. Unlike many conventional books on architecture that pretend to present a "theory" - but instead often are just specialized overviews of recycled fashionable, theoretical concepts (like most writings on architecture's "deconstruction") - the team of Mehaffy and Salingaros gives both a scientific account of things and explains how scientific methods can be appropriated for the use in the built environment: "But as we noted earlier, too often, we humans tend to treat the products around us as separated things of very limited function that we can choose to isolate or recombine at our whim, with little consequence. This is functionally speaking a mistake. According to a key principle from systems theory, we can only treat systems as closed, up to a point. Ultimately we have to see the ways in which all systems are partly open and inter-connected. Biological and ecological systems - of which we humans are ultimately an inseparable part - are open systems."

A key lesson for designers of all kinds follows: product design can't really be separated from environmental design. We are all, in some sense, environmental designers, working in the human environment. Since every system is only partially closed, we have to find ways to work on these systems as open systems - that is, as parts of larger, optimizing wholes. Routine failure to do so, has led to our ecological misfortunes." (p. 117). One can only add that a large part of architectural modernism and urban design was and continues to be a product of thinking of it as a closed system. What we urgently need is not only to remap it in terms of open systems, but to make them real and working in the upcoming decades that threaten to take a form of "dark age ahead" as Jane Jacobs has warned us - unless we become serious about the pressing changes needed in thinking and practice. 